\title{
Neuropathogenesis of Simian Immunodeficiency Virus infection in macaque monkeys
}

\author{
Vito G Sasseville and Andrew A Lackner \\ Division of Comparative Pathology, Harvard Medical School, New England Regional Primate Research Center, \\ Southborough, Massachusetts 01772, USA
}

\begin{abstract}
Patients infected with human immunodeficiency virus (HIV) develop immunologic dysfunction and multiorgan inflammatory diseases directly associated with HIV-1 infection. Of these inflammatory diseases, the most devastating to the HIV-infected patient is involvement of the central nervous system (CNS). The pathogenesis of the clinical syndrome observed in these patients, termed HIV-associated dementia, remains poorly understood. However, as most of the detectable virus in the CNS is in cells of monocyte/ macrophage lineage, it is clear that penetration of the blood-brain barrier by HIV-1 and the subsequent influx of monocytes into the brain are crucial components in the neuropathogenesis of HIV-associated dementia. Using the SIV-infected macaque model of acquired immunodeficiency disease, much has been learned about viral neuroinvasion occurring soon after experimental infection. The aim of this review is to discuss these recent advances and provide insight into plausible mechanisms for monocyte entry into the CNS.
\end{abstract}

Keywords: human immunodeficiency virus; simian immunodeficiency virus; acquired immune deficiency syndrome; HIV-associated dementia; rhesus macaques

\section{Introduction}

Approximately $25 \%$ of human immunodeficiency virus type 1 (HIV-1)-infected individuals develop neurologic disease (Janssen et al, 1991; McArthur, 1996). The clinical syndrome observed in these patients, termed HIV-associated dementia, is characterized by a range of cognitive, motor and behavioral changes (Michaels et al, 1988; Persidsky et al, 1995; Price et al, 1987, 1988). A correlation between HIV-associated dementia and the presence of HIV-1 in the central nervous system (CNS) (Wiley and Achim, 1994), dendritic pathology (Masliah et al, 1992), neuronal loss (Everall et al, 1991; Ketzer et al, 1990), the spatial pattern of neurons (Asare et al, 1996) and increased numbers of macrophages in the brain (Glass et al, 1995) has been shown. Despite these advances, the pathogenesis of HIVassociated dementia remains an enigma.

Many individuals with HIV-associated dementia also have HIV encephalitis (HIVE). HIVE is defined by the presence of charactersitic histopathologic

Correspondence: Vito G Sasseville

Received 4 October 1996; accepted 8 October 1996 changes and/or detectable HIV-1 nucleic acid or antigen in the CNS (Budka et al, 1991b). The typical lesions of HIVE are astrocytosis, glial nodules and parenchymal and perivascular infiltrates of macrophages and multinucleate giant cells (Kure et al, 1990; Nielsen et al, 1984; Price et al, 1988; Wiley et al, 1986). HIV antigens, nucleic acid and viral particles have been consistently localized to macrophages/microglia in these lesions (Epstein et al, 1985; Gyorkey et al, 1987; Koenig et al, 1986). Evidence for infection of astrocytes, oligodendrocytes, endothelial cells and neurons is less convincing (Koenig et al, 1986; Moses et al, 1993; Saito et al, 1994; Tornatore et al, 1994; Wiley et al, 1986). Thus, as productive HIV-1 infection in HIVE is primarily confined to macrophage/microglial infiltrates in the CNS, the mechanisms of neuronal dysfunction are unclear. For these reasons research on the pathogenesis of this disorder has focused on indirect mechanisms of neuronal dysfunction and death (Bernton et al, 1992; Brenneman et al, 1988; Genis et al, 1992; Giulian et al, 1990; Lipton, 1991; Pulliam et al, 1991). These studies suggest that the keystone of HIV-associated dementia is the HIV-1- 
infected brain macrophage/microglial cell that either produces or induces other CNS resident cells to release factors that ultimately result in neuronal injury. Thus, while a direct relationship between HIV-infected macrophages/microglia and neuropathology is evident, the association between neuropathology and the clinical disorder remains controversial (Wiley and Achim, 1995). Nor do we understand the inciting mechanisms responsible for initial monocyte/macrophage recruitment to the brain during HIV-1 infection.

\section{SIV-infected macaque monkey model}

Similar to HIV-1-infected patients, many simian immunodeficiency virus (SIV)-infected macaque monkeys develop lentivirus-induced encephalitis (SIV encephalitis, SIVE) (Table 1). SIVs are immunosuppressive nonhuman primate lentiviruses that have extensive sequence homology, morphology, and biologic properties similar to HIV-1 and HIV-2 (Desrosiers et al, 1990). As with HIV-1, the target for SIV infection in vivo and in vitro (Desrosiers et al, 1991; Lackner et al, 1991; Ringler et al, 1989; Wyand et al, 1988) is the CD4 molecule expressed on lymphocytes and monocyte/macrophages. Moreover, as with HIV-1, SIV isolated from encephalitic brains has been shown to be macrophage-tropic (Desrosiers et al, 1991; Simon et al, 1992, 1994; Watkins et al, 1990; Wiley and Budka, 1991). Even when animals are infected with molecularly cloned lymphotropic virus (eg SIVmac239), approximately $30 \%$ of infected animals develop highly macrophage-competent variants (Desrosiers et al, 1991). Macrophage tropism of SIVmac239 variants and high levels of virus replication in the CNS have been associated with specific sequence changes in the env gene (Kodama et al, 1993; Mori et al, 1992). Thus, as neuronal dysfunction in many patients with HIVassociated dementia is most likely a result of macrophage/microglial infection (Budka, 1991), the SIV-infected macaque monkey is an excellent model for examining how monocytes/macrophages infiltrate the CNS.

Table 1 Comparison of human and simian immunodeficiancy virus infection of the nervous system

\begin{tabular}{lcc}
\hline & $H I V$ & $S I V$ \\
\hline $\begin{array}{lcc}\text { Encephalitis } \\
\text { multinucleate giant cells }\end{array}$ & + & + \\
vascular orientation & + & + \\
mineralization & pediatric cases & juvenile/adults \\
atrophy & + & + \\
white matter pallor & + & - \\
Myelitis & & + \\
multinucleate giant cells & + & rare \\
vacuolar myelopathy & + & + \\
Behavioural alterations & + & - \\
Peripheral neuropathy & + & rare \\
Opportunistic infections & common in & \\
& adults &
\end{tabular}

Early events in lentivirus invasion of the CNS A major unanswered question is why only a portion of HIV-infected patients and SIV-infected monkeys develop HIVE and SIVE. There is a strong association between macrophage-tropism and HIVE/SIVE. There is also evidence that the host immune system plays a major role in controlling viral infection in the CNS (Bell et al, 1993; Nathanson et al, 1994). To answer this question, one has to look at how virus and host interact early in infection. Soon after infection, during peak viremia which occurs just prior to or at the time of seroconversion (Gaines et al, 1987), HIV-1 is frequently isolated from the cerebrospinal fluid (CSF) in both symptomatic (Albert et al, 1987; Gaines et al, 1987; Gouldsmit et al, 1986; Ho et al, 1985) and asymptomatic (Chiodi et al, 1986, 1988; Sinclair et al, 1992) patients. A subpopulation of patients will develop an acute meningoencephalitis (Carne et al, 1985; Cooper et al, 1985). Generally, following this acute phase of primary lentivirus infection, the onset of an immune response is associated with a decrease of HIV antigen and virus in the CNS (Gaines et al, 1987; Gouldsmit et al, 1986). During this asymptomatic phase of infection, neurologic signs may be absent, but patients may have chronic or subacute meningoencephalitis. Patients who progress to advanced HIVE usually have decreased immune function with a transition to symptomatic AIDS (Bell et al, 1993; Chiodi and Fenyö, 1991; Michaels et al, 1988; Price et al, 1987; Rhodes, 1993; Sharer et al, 1991). Similarly, in macaque monkeys infected with SIV there is a very early burst in viral replication in both lymphoid organs and the CNS. We have shown that even molecularly cloned lymphotropic virus (SIVmac239) induces an acute meningoencephalitis indistinguishable from that induced by other pathogenic isolates of SIV by 2 weeks postinoculation (Lackner et al, 1994). These initial rounds of viral replication decrease as the host immune system responds (Lackner et al, 1994; Reimann et al, 1994). In the CNS, as in the lymphoid tissues, both SIV-specific cytotoxic lymphocytes and antibody are involved (Smith et al, 1995; Von Herrath et al, 1995). Similar to HIV-infected patients, as the disease progresses and the immune system fails, a portion of the animals develop SIVE. Thus, sometime early in infection or during the asymptomatic period unique viral and host factors in conjunction with viral entry into the CNS are likely responsible for progression to SIVE. In order to elucidate the pathogenesis of this complex disease, factors involved in viral entry into the brain have to be closely examined at the level of initial leukocyte interaction with CNS endothelium.

\section{Leukocyte and endothelial interactions}

It is widely assumed that HIV-1 enters the brain within monocytes (Trojan horse theory) (Peluso et 
al, 1985). Whether these monocytes migrate into the brain as part of the normal replacement of resident perivascular macrophages or in response to activation and subsequent chemotactic stimuli is unknown. In addition, the role of the endothelial cell may be crucial. To address these questions, one has to consider the unique interplay of circulating leukocytes and CNS endothelium. The brain is one of the 'privileged' sites in the body: the circulatory system and the CNS parenchyma are physically separated. This separation, called the blood-brain barrier (BBB), is maintained by tight junctions between brain endothelial cells, intact basement membranes, and the perivascular glia limitans composed of astroglial and perivascular macrophage cell foot processes (Lassmann et al, 1991). Of these components, macrophages/microglia are the primary cells infected with HIV/SIV and thus the focus of attention for pathogenesis studies.

There are five separate populations of brain macrophages: the parenchymal (resident microglia), choroid plexus, meningeal, gitter cell, and perivascular. Of these, the meningeal and perivascular macrophages may play a significant role in antigen presentation and activation of immune responses (Altman, 1994; Hickey et al, 1991; Hickey and Kimura, 1988; Lassmann et al, 1991). Although phenotypically and functionally similar to non-CNS tissue macrophages and parenchymal microglia, these perivascular macrophages may differ in origin and turnover rate in both normal and inflamed CNS (Lassman et al, 1993). In normal adult rodent and human brain, it has been shown that perivascular macrophages are replaced continuously via recruitment from the circulating monocyte pool through the intact BBB (Hickey and Kimura, 1988; Lawson et al, 1992; Unger et al, 1993). Thus, HIV/SIVinfected monocytes may enter the CNS parenchyma in the absence of concurrent inflammation (Figure 1). Furthermore, studies in Lewis rats have demonstrated that recruitment of perivascular macrophages is accelerated during CNS inflammation, while the resident parenchymal microglia are seldom replaced by hematogenous cells (Lassman

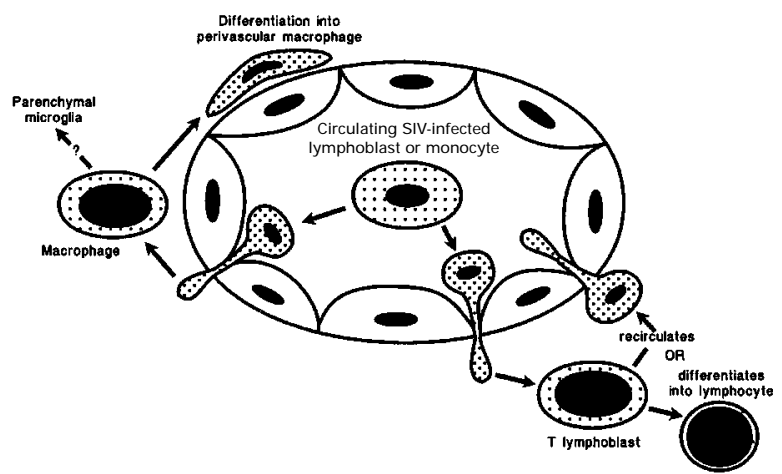

Figure 1 Theorectical model of cell-associated SIV invasion of the CNS utilizing normal leukocyte trafficking mechanisms et al, 1993). Moreover, activated macrophages can in turn activate other cell types, notably, astrocytes and endothelium, via secretion of IL- $1 \beta$, TGF- $\beta$, and TNF- $\alpha$ (Giulian et al, 1986; Selmaj et al, 1990). IL-1 $\beta$ and TNF- $\alpha$ are potent inducers of endothelial adhesion molecules in vitro and in vivo (Bevilacqua and Nelson, 1993; Bevilacqua et al, 1985; Briscoe et al, 1992; Dustin et al, 1986) and probably are crucial in recruitment of leukocytes to the CNS in HIVE. Thus, HIV/SIV-infected circulating monocytes may be a source of CNS infection via the natural or accelerated replacement of perivascular macrophages (Figure 1). In our studies using the acutely SIV-infected macaque monkey model, neuroinvasion by SIV has been associated with intrathecal immune activation (Sasseville et al, 1995; Smith et al, 1992). Significant increases in the density of perivascular macrophages/microglia coincide with viral neuroinvasion and marked elevation of CSF quinolinic acid (Lane et al, 1996). Moreover, in support of the Trojan horse theory, combined in situ hybridization and immunohistochemistry demonstrate that these infected perivascular cells are macrophages/microglia (Lane et al, 1996).

Studies in rats have also demonstrated that $\mathrm{T}$ lymphoblasts, but not mature T-cells, randomly enter the CNS (Figure 1). However, in the absence of specific antigen recognition they exit within 1 to 2 days (Hickey et al, 1991) (Figure 1). Thus, HIV/SIVinfected T-lymphoblasts may also be a potential source of initial HIV-1 infection of the CNS. What effect normal or augmented cell trafficking to the CNS has on the development of HIV-induced CNS disease is unknown and needs to be examined.

\section{Role of adhesion molecules and chemokines in neuroinvasion}

Although the mechanisms governing recruitment of leukocytes to the CNS from the systemic circulation are not fully characterized, upregulation of leukocyte and endothelial adhesion molecules and chemoattractants (eg chemokines) are likely critical components (Miller and Krangel, 1992; Springer, 1994). It is well established that the sequential interactions of selectins, integrins and members of the immunoglobulin gene superfamily and their corresponding ligands are crucial for leukocyte rolling, firm adhesion, and transendothelial migration at sites of tissue injury (Springer, 1994). In fact, numerous in vivo studies have demonstrated that monoclonal antibody blockade of these pathways significantly reduces the influx of cellular infiltrates into inflamed tissues. For instance, in rodent experimental allergic encephalomyelitis (EAE), a model of multiple sclerosis, mononuclear cell infiltrates were abrogated by blockade of the VCAM-1/ $\alpha 4 \beta 1$ pathway (Baron et al, 1993; Yednock et al, 1992). Likewise, we have demonstrated upregulated VCAM-1 in macaque monkeys with SIVE and documented that VCAM-1/ $\alpha 4 \beta 1$ interac- 
tions are involved in monocyte adherence to endothelium in encephalitic brain (Sasseville et al, 1992, 1994). In addition, human brain microvascular endothelial cells cocultured with activated HIV-infected monocytes express elevated levels of VCAM-1 and E-selectin (Nottet et al, 1996). Elevated levels of these two adhesion molecules paralleled the levels of HIV-1 gene products and proinflammatory cytokines in encephalitic brain from HIV-1-infected patients (Nottet et al, 1996). Studies utilizing the SCID mouse model of HIVE demonstrate the direct relationship between macrophage/microglia activation, which occurs in response to neuroinvasion of HIV-1-infected monocytes, and subsequent VCAM-1 expression by CNS endothelial cells and monocyte infiltration into the CNS (Persidsky et al, 1996). Taken together, these studies strongly support a role for cytokineinduced endothelial adhesion molecules in leukocyte recruitment to the CNS in HIVE/SIVE.

In addition to the interactions of leukocyte and endothelial adhesion molecules, monocytes are also activated and migrate in response to chemotactic gradients elicited from inflammatory sites (Furie and Randolf, 1995; Springer, 1994). Pivotal components of this process are a group of chemotactic cytokines, termed chemokines. Chemokines are structurally related, low-molecular-weight, proinflammatory proteins that are induced in various cell types (including endothelial cells and leukocytes) and are distinct from classical chemoattractants in that they affect the migration of specific subsets of leukocytes (Schall et al, 1990, 1993; Taub et al, 1993). Based on the presence or absence of an amino acid separating the first pair of cysteines, they are divided into two subfamilies ( $\alpha$ or $\mathrm{C}-\mathrm{X}-\mathrm{C}$ and $\beta$ or $\mathrm{C}$ $\mathrm{C}$ chemokines). For the most part, the C-X-C chemokines stimulate and attract neutrophils, whereas the C-C chemokines activate and attract monocytes, lymphocytes and eosinophils (Furie and Randolf, 1995; Loetscher et al, 1994b; Rot et al, 1992; Schall et al, 1993). Although these chemokines are potent mediators of inflammation, recent studies have focused on their antiviral properties.

The C-C chemokines, RANTES (regulated on activation normal $\mathrm{T}$ cell expressed and secreted) and macrophage inflammatory protein- $1 \alpha$ and $-\beta$ (MIP- $1 \alpha$ and $\beta$ ) have been shown to be major HIVsuppressive factors released by $\mathrm{CD}^{+}$cells (Cocchi et al, 1995). Another group of investigators showed elevated levels of these three chemokines in purified populations of $\mathrm{CD}^{+}$lymphocytes from HIV-negative individuals who were repeatedly exposed to HIV (Paxton et al, 1996). Moreover, they showed that these $\mathrm{CD}^{+}$lymphocytes were more resistant to in vitro infection with multiple primary isolates to HIV-1 than were CD4+ lymphocytes isolated from nonexposed individuals (Paxton et al, 1996). Exactly how these chemokines exerted their effect was not resolved in these studies. For years investigators have been searching for a coreceptor that acts in conjunction with CD4, which dictates $\mathrm{T}$ cell- and/or macrophagetropism of HIV/SIV isolates. Recently, Feng et al. reported that a fusion receptor ('fusin' or LESTR) along with CD4 enables $\mathrm{T}$ cell line-tropic HIV isolates to infect lymphocytes (Feng et al, 1996). Moreover, antibodies against LESTR/fusin blocked envelope-mediated fusion and viral entry into susceptible cells (Feng et al, 1996). This cofactor, a putative seven-transmembrane, $G$ proteincoupled receptor is similar $(37 \%$ amino acid identity) to the receptor for the C-X-C chemokine interleukin-8 (Feng et al, 1996; Loetscher et al, 1994a). More recently, the lymphocyte chemoattractant stromal cell-derived factor-1 (SDF-1) has been shown to be the natural ligand for LESTR/ fusin (Bleul et al, 1996; Oberlin et al, 1996). In cells expressing CD4 and LESTR/fusin, SDF-1 inhibits infection by T-cell tropic strains of HIV (Bleul et al, 1996; Oberlin et al, 1996). Therefore, some chemokine receptors may function as fusin cofactors, but MIP- $1 \alpha$, MIP- $1 \beta$ and RANTES do not bind to LESTR/fusin. Which receptors are responsible for the antiviral activity of MIP-1 $\alpha$, MIP- $1 \beta$ and RANTES? Many independent groups have identified the C-C chemokine receptor 5 (CCCKR5) as the major coreceptor for macrophagetropic strains of HIV-1 (Choe et al, 1996; Deng et al, 1996; Doranz et al, 1996; Dragic et al, 1996). However, additional chemokine receptors, CCCKR2b and CC-CKR3, are utilized by other HIV-1 isolates (Choe et al, 1996; Doranz et al, 1996). In agreement with earlier observations that macrophage-tropism of HIV/SIV isolates is determined by sequence variations in the V3 loop of HIV-1 gp120 (Korber et al, 1994; Power et al, 1994). Choe et al demonstrated that the utilization of specific chemokine receptors by $\mathrm{T}$ cell- or macrophagetropic isolates was dictated by the sequence of the V3 region (Choe et al, 1996). Thus, these findings demonstrate that some monocyte-tropic strains of HIV-1 utilize C-C chemokine receptors (eg CCCKR5) as coreceptors for infection, whereas T celltropic HIV-1 strains use C-X-C receptors (eg LESTR/fusin).

Despite strong in vitro data demonstrating the antiviral properties of certain chemokines, in vivo data from our laboratory and others reveal that elevated chemokines do not appear to prevent virus infection in the CNS. Brain from patients with HIVassociated dementia showed more MIP- $1 \alpha$ and MIP$1 \beta$ mRNA than brain from HIV-infected patients without dementia (Schmidtmayerova et al, 1996). Recently, we have demonstrated that encephalitic brain from SIV-infected animals has elevated immunohistochemical expression of MIP-1 $\alpha$, MIP$1 \beta$, RANTES, monocyte chemotactic protein-3 (MCP-3), and interferon-inducible protein-10 (IP- 
10) (Sasseville et al, 1996). These results in SIVinfected macaque monkeys and HIV-infected patients demonstrating elevated immunohistochemical expression of chemokines on endothelium and perivascular infiltrates in encephalitic brain containing abundant virus suggest that at least in the brain these chemokines play no role in containing viral replication, and probably function as mediators of inflammation. MIP- $1 \alpha$ and MIP- $1 \beta$ are potent chemoattractants for monocytes and lymphocytes (Koch et al, 1994; Taub et al, 1993) and in conjunction with cytokine-induced adhesion molecule expression provide a likely mechanism for monocyte recruitment to the CNS in HIV-infected patients. However, the in vivo role of chemokines in HIV infection remains to be determined.

\section{Summary}

From our time-course studies of SIV-infected macaque monkeys early after experimental infection, we have begun to unravel some of the complex interactions in initial viral neuroinvasion. In agreement with the Trojan horse theory of neuroinvasion, we have demonstrated that, independent of cellular tropism of the initial virus (macrophage- or T celltropic), SIV enters the CNS within 2 weeks of infection. Coincident with viral neuroinvasion, there is a significant increase in the density of perivascular macrophages/microglia and evidence of macrophage activation (i.e. increased quinolinic acid levels). We hypothesize that virus within infected circulating monocytes enters the CNS by natural or increased trafficking mechanisms (Figure 1). Once extravasated, these virus-infected activated monocytes differentiate and become further activated and release cytokines and chemokines that stimulate surrounding resident cells (eg, macrophage/microglia, astrocytes, endothelium) (Figure 2). In particular, the CNS endothelium produces and binds chemokines, increasing the chemotactic gradient, and increases expression of cytokine-inducible adhesion molecules that bind circulating leukocytes, augmenting leukocyte recruitment (Figure 2).

With the onset of an immune response to SIV, virus recovery from the CSF, the density of perivascular macrophages and quinolinic acid levels decrease sharply. However, the few animals, termed rapid progressors, that fail to mount a significant immune response to SIV generally have the highest density of perivascular macrophages and VCAM-1 expression. Some of these animals will develop fulminant SIVE. Thus, early after infection there is a strong association between lack of an immune response to SIV and the development of SIVE.

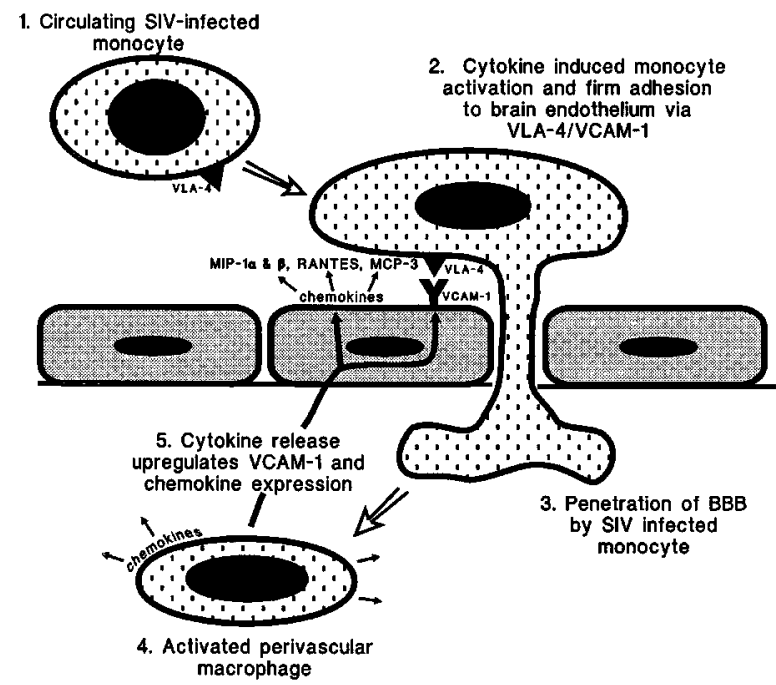

Figure 2 Theorectical model of recruitment of SIV-infected leukocytes via activated CNS endothelium. SIV-infected leukocytes enter the CNS through normal or enhanced trafficking mechanisms causing localized endothelial activation (chemokine release and upregulation of adhesion molecules). Additional circulating activated SIV-infected leukocytes (particularly monocytes) with upregulated surface integrin receptors (1) selectivity bind to activated endothelium (2); penetrate the blood-brain barrier (3); differentiate into perivascular macrophages and become further activated (4), and release additional cytokines and chemokines augmenting the chemoattraction and adhesion molecule expression on surrounding leukocytes and endothelium (5). This results in increased recruitment of leukocytes into the CNS further amplifying the process

The pathogenesis is less clear in the animals that are able to mount an initial immune response to SIV and to clear virus from the CNS but subsequently develop terminal SIVE. We know that adhesion molecule and chemokine expression is elevated in all animals with SIVE, whether they are classified as rapid progressors or not. Thus, in terminal AIDS is it the enhanced localized expression of adhesion molecules and chemokines and increased cellular trafficking to the CNS that allows SIV to reenter the CNS, or is the virus crossing the BBB first and the subsequent induction of these factors that set the stage for SIVE to develop?

\section{Acknowledgements}

We thank Dr. Kenneth C Williams for helpful discussions; Alison Hampson for photography; and Douglas R Pauley for editorial assistance. Grant support: Public Health Service Awards AI25644, NS33820, NS30769 and RR00168. 


\section{References}

Albert J, Gaines H, Sönnerborg A, Nyström G, Pehrson PO, Chiodi F, van Sydow M, Moberg L, Lidman K, Christensson B, Asjö B, Fenyö EM (1987). Isolation of the human immunodeficiency virus (HIV) from plasma during primary HIV infection. J Med Virol 23: $67-73$.

Altman J (1994). Microglia emerge from the fog. TINS 17: $49-50$.

Asare E, Dunn G, Glass J, McArthur J, Luthert P, Lantos P, Everall I (1996). Neuronal pattern correlates with the severity of human immunodeficiency virusassociated dementia complex. Am J Pathol 148: $31-$ 38.

Baron JL, Madri JA, Ruddle NH, Hashim G, Janeway C Jr (1993). Surface expression of $\alpha 4$ integrin by CD4 T cells is required for their entry into brain parenchyma. $J$ Exp Med 177: 57-68.

Bell JE, Busuttil A, Ironside JW, Rebus S, Donaldson YK, Simmonds P, Peutherer JF (1993). Human immunodeficiency virus and the brain: Investigation of virus load and neuropathologic changes in preAIDS subjects. I Infect Dis 168: 818-824.

Bernton E, Bryant H, Decoster M, Orenstein JM, Ribas J, Meltzer MS, Gendelman HE (1992). No direct neuronotoxicity by HIV-1 virions or culture fluids from HIV-1-infected T cells or monocytes. AIDS Res Hum Retroviruses 8: 495

Bevilacqua MP, Nelson RM (1993). Selectins. J Clin Invest 91: $379-387$.

Bevilacqua MP, Pober JS, Wheeler ME, Cotran RS, Gimbrone M Jr (1985). Interleukin 1 acts on cultured human vascular endothelium to increase the adhesion of polymorphonuclear leukocytes, monocytes, and related leukocyte cell lines. J Clin Invest 76: 20032011.

Bleul CC, Farzan M, Choe H, Parolin C, Clark-Lewis I, Sodroski J, Springer TA (1996). The lymphocyte chemoattractant SDF-1 is a ligand for LESTR/fusin and blocks HIV entry. Nature 382: 829-833.

Brenneman DE, Westbrook GL, Fitzgerald SP, Ennist DL, Elkins KL, Ruff MR, Pert CB (1988). Neuronal cell killing by the envelope protein of HIV and its prevention by vasoactive intestinal peptide. Nature 335: $639-642$.

Briscoe DM, Cotran RS, Pober JS (1992). Effects of tumor necrosis factor lipopolysaccharide, and IL-4 on the expression of vascular cell adhesion molecule-1 in vivo. J Immunol 149: 2954-2960.

Budka H (1991). Neuropathology of human immunodeficiency virus infection. Brain Pathol 1: $163-175$.

Budka H, Wiley CA, Kleihues P, Artigas J, Asbury AK, Cho E-S, Cornblath DR, Dal Canto MC, DeGirolami U, Dickson D, Epstein LG, Esiri MM, Giangaspero F, Gosztonyi G, Gray F, Griffin JW, Henin D, Iwasaki Y, Janssen RS, Johnson RT, Lantos PL, Lyman WD, McArthur JC, Nagashima K, Peress N, Petito CK, Price RW, Rhodes RH, Rosenblum M, Said G, Scaravilli F, Sharer LR, Vinters HV. (1991). HIV-associated disease of the nervous-system: review of nomenclature and proposal for neuropathology-based terminology. Brain Pathol 1: $143-152$.
Carne CA, Tedder RS, Smith A, Sutherland S, Elkington SG, Daly HM, Preston E, Craske J (1985). Acute encephalopathy coincident with seroconversion for anti-HTLV-III. Lancet ii: 1206-1208.

Chiodi F, Albert J, Olausson E, Hagberg L, Sönnerborg A, Åsjö B, Fenyö EM (1988). Isolation frequency of human immunodeficiency virus from cerebrospinal fluid and blood of patients with varying severity of HIV infection. AIDS Res Hum Retro 4: 351-358.

Chiodi F, Åsjö B, Fenyö EM, Norkrans G, Hagberg L, Albert J (1986). Isolation of the human immunodeficiency virus from the cerebrospinal fluid of an antibody positive virus carrier without neurological symptoms. Lancet ii: 1276-1277.

Chiodi F, Fenyö EM (1991). Neurotropism of human immunodeficiency virus. Brain Pathol 1: 185-191.

Choe H, Farzam M, Sun Y, Sullivan N, Rollins B, Ponath P, Wu L, Mackay CR, LaRosa G, Newman W, Gerard $\mathrm{N}$, Gerard C, Sodroski J (1996). The $\beta$-chemokine receptors CCR3 and CCR5 facilitate infection by primary HIV-1 isolates. Cell 85: 1135-1148.

Cocchi F, DeVico AL, Garzino-Demo A, Arya SK, Gallo RC, Lusso P (1995). Identification of RANTES, MIP- $1 \alpha$, and MIP- $1 \beta$ as the major HIV-suppressive factors produced by CD8+ T cells. Science 270: 1811-1815.

Cooper DA, Gold J, Maclean P, Donovan B, Finlayson R, Barnes TG, Michelmore HM, Brooke P, Penny R (1985). Acute AIDS retrovirus infection: Definition of a clinical illness associated with seroconversion. Lancet i: $537-540$.

Deng H, Liu R, Ellmeier W, Choe S, Unutmaz D, Burkhart M, Di Marzio P, Marmon S, Sutton RE, Hill CM, Davis CB, Peiper SC, Schall TJ, Littman DR, Landau NR (1996). Identification of a major coreceptor for primary isolates of HIV-1. Nature 381, $661-666$.

Desrosiers RC (1990). The simian immunodeficiency viruses. Annu Rev Immunol 8: 557-578.

Desrosiers RC, Hansen-Moosa A, Mori K, Bouvier DP, King NW, Daniel MD, Ringler DJ (1991). Macrophagetropic variants of SIV are associated with specific AIDS-related lesions but are not essential for the development of AIDS. Am J Pathol 139: 29-35.

Doranz BJ, Ruchker J, Yi Y, Smyth RJ, Samson M, Peiper SC, Parmentier M, Collman RG, Doms RW (1996). A dual-tropic primary HIV-1 isolate that uses fusin and the $\beta$-chemokine receptors CKR-5, CKR-3, and CKR-2b as fusion cofactors. Cell 85: 1149-1158.

Dragic T, Litwin V, Allaway GP, Martin SR, Huang Y, Nagashima KA, Cayanan C, Maddon PJ, Koup RA, Moore JP, Paxton WA (1996). HIV-1 entry into CD4+ cells is mediated by the chemokine receptor CC-CKR5. Nature 381: 667-673.

Dustin ML, Rothlein R, Bhan AK, Dinarello CA, Springer TA (1986). Induction by IL-1 and interferon- $\gamma$ : tissue distribution, biochemistry, and function of a natural adherence molecule (ICAM-1). I Immunol 137: 245254.

Esptein LG, Sharer LR, Cho ES, Meyenhofer M, Navia BA, Price RW (1985). HTLV-III/LAV-like retrovirus particles in the brains of patients with AIDS encephalopathy. AIDS Res 1: 447-454. 
Everall IP, Luthert PJ, Lantos PL (1991). Neuronal loss in the frontal cortex in HIV infection. Lancet 337: 11191121.

Feng Y, Broder CC, Kennedy PE, Berger EA (1996). HIV1 entry cofactor: functional cDNA cloning of a seventransmembrane, G protein-coupled receptor. Science 272: $872-877$.

Furie MB, Randolf GJ (1995). Chemokines and tissue injury. Am J Pathol 146, 1287-1301.

Gaines H, von Sydow M, Sönnerborg A, Albert J, Czajkowski J, Pherson PO, Chiodi F, Moberg L, Fenyö EM, Åsjö B, Forsgren M (1987). Antibody response in primary human immunodeficiency virus infection. Lancet i: 1249-1253.

Genis P, Jett M, Bernton EW, Boyle T, Gelbard HA, Dzenko K, Keane RW, Resnick L, Mizrachi Y, Volsky DJ, Epstein LG, Gendelman HE (1992). Cytokines and arachidonic metabolites produced during human immunodeficiency virus (HIV)-infected macrophageastroglia interactions: implications for the neuropathogenesis of HIV disease. J Exp Med 176: $1703-1718$

Giulian D, Baker TJ, Shih LN, Lachman LB (1986). Interleukin 1 of the central nervous system is produced by ameboid microglia. J Exp Med 164: 594-604.

Giulian D, Vaca K, Noonan CA (1990). Secretion of neurotoxins by mononuclear phagocytes infected with HIV-1. Science 250: 1593-1596.

Glass JD, Fedor H, Wesselingh SL, McArthur JC (1995). Immunocytochemical quantitation of human immunodeficiency virus in the brain: correlations with dementia. Ann Neurol 38: 755-762.

Gouldsmit J, De Wolf F, Paul DA, Epstein LG, Lange JMA, Krone WJA, Speelman H, Wolters EC, Van Der Noordaa J, Oleske JM, Van Der Helm HJ, Coutinho RA (1986). Expression of human immunodeficiency virus antigen (HIV-Ag) in serum and cerebrospinal fluid during acute and chronic infection. Lancet ii: 177180.

Gyorkey F, Melnick JL, Gyorkey P (1987). Human immunodeficiency virus in brain biopsies of patients. J Infect Dis 155: 870-876.

Hickey WF, Hsu BL, Kimura H (1991). T-lymphocyte entry into the central nervous system. $J$ of Neuroscience Res 28: 254-260.

Hickey WF, Kimura H (1988). Perivascular microglial cells of the CNS are bone marrow-derived and present antigen in vivo. Science 239: 290-292.

Ho DD, Rota TR, Schooley RT, Kaplan JC, Allan JD, Groopman JE, Resnick L, Felsenstein D, Andrews CA, Hirsch MS (1985). Isolation of HTLV-III from cerebrospinal fluid and neural tissues of patients with neurologic syndromes related to the acquired immunodeficiency syndrome. $N$ Engl J Med 313: $1493-1497$.

Janssen RS, Cornblath DR, Epstein LG, Foa RP, McArthur JC, Price RW, Asbury AKK, Beckett A, Benson DF, Bridge TP, Leventhal CM, Satz P, Saykin AJ, Sidtis JJ, Tross S (1991). Nomenclature and research case definitions for neurologic manifestations of human immunodeficiency virus type 1 (HIV-1) infection. Neurology 41: 778-785.

Ketzler S, Weis S, Haug H, Budka H (1990). Loss of neurons in the frontal cortex in AIDS brains. Acta Neuropathol 80: $92-94$.
Koch AE, Kunkel SL, Harlow LA, Mazarakis DD, Haines GK, Burdick MD, Pope RM, Strieter RM (1994). Macrophage Inflammatory Protein-1 $\alpha$ : a novel chemotactic cytokine for macrophages in rheumatoid arthritis. J Clin Invest 93: 921-928.

Kodama T, Mori K, Kawahara T, Ringler DJ, Desrosiers RC (1993). Analysis of simian immunodeficiency virus sequence variation in tissues of rhesus macaques with AIDS. J Virol 67: 6522-6534.

Koenig S, Gendelman HE, Orenstein JM, Dal Canto MC, Pezeshkpour GH, Yungbluth M, Janotta F, Aksamit A, Martin MA, Fauci AS (1986). Detection of AIDS virus in macrophages in brain tissue from AIDS patients with encephalopathy. Science 233: 1089-1093.

Korber BTM, Kunstman KJ, Patterson BK, Furtado M, McEvilly M, Levy R, Wolinsky SM (1994). Genetic differences between blood- and brain-derived viral sequences from human immunodeficiency virus type 1-infected patients: evidence of conserved elements in the $\mathrm{V} 3$ region of the envelope protein of brain-derived sequences. J Virol 68: 7467

Kure K, Lyman WD, Weidenheim KM, Dickson DW (1990). Cellular localization of an HIV-1 antigen in subacute AIDS encephalitis using an improved double-labeling immunohistochemical method. Am J Pathol 136: 1085-1092.

Lackner A, Vogel P, Ramos R, Kluge J, Marthas M (1994). Early events in tissues during infection with pathogenic (SIVmac239) and nonpathogenic (SIVmac1A11) molecular clones of SIV. Am I Pathol 145: $428-439$

Lackner AA, Smith MO, Munn RJ, Martfeld DJ, Gardner MB, Marx PA, Dandekar S (1991). Localization of simian immunodeficiency virus in the central nervous system of rhesus monkeys. Am J Pathol 139: 609621.

Lane JH, Sasseville VG, Smith MO, Vogel P, Pauley DR, Heyes MP, Lackner AA (1996). Neuroinvasion by simian immunodeficiency virus coincides with increased numbers of perivascular macrophages/ microglia and intrathecal immune activation. $J$ Neurovirol (in press).

Lassman H, Schmied M, Vass K, Hickey WF (1993). Bone marrow derived elements and resident microglia in brain inflammation. Glia 7: 19-24.

Lassmann H, Zimprich F, Vass K, Hickey WF (1991). Microglial cells are a component of the perivascular glia limitans. J Neurosci Res 28: 236-243.

Lawson LJ, Perry VH, Gordon S (1992). Turnover of resident microglia in the normal adult mouse brain. Neuroscience 48: 405-415.

Lipton SA (1991). HIV-related neurotoxicity. Brain Pathol 1: 193-199.

Loetscher M, Gesier T, O'Reilly T, Zwahlen R, Baggiolini M, Moser B (1994a). Cloning of a human seventransmembrane domain receptor, LESTR, that is highly expressed in leukocytes. J Biol Chem 269: $232-237$.

Loetscher P, Seitz M, Clark-Lewis I, Baggiolini M, Moser B (1994b). Monocyte chemotactic proteins MCP-1, MCP-2, MCP-3 are major attractants for human CD4+ and CD8+ T lymphocytes. FASEB J 8: 1055-1060.

Masaliah E, Ge N, Morey M, DeTeresa R, Terry RD, Wiley CA (1992). Cortical dendritic pathology in human immunodeficiency virus encephalitis. Lab Invest 66: $285-291$. 
McArthur JC (1996). HIV dementia: 10 years on. J Neurovirol 2: 8.

Michaels J, Sharer LR, Epstein LG (1988). Human immunodeficiency virus type 1 (HIV-1) infection of the nervous system: a review. Immunodefic Rev 1: $71-104$.

Miller MD, Krangel MS (1992). Biology and biochemistry of the chemokines: a family of chemotactic and inflammatory cytokines. Crit Rev in Immunol 12: $17-46$.

Mori K, Ringler DJ, Kodama T, Desrosiers RC (1992). Complex determinants of macrophage tropism in env of simian immunodeficiency virus. I Virol 66: 20672075.

Moses AV, Bloom FE, Pauza D, Nelson JA (1993). Human immunodeficiency virus infection of human brain capillary endothelial cells occurs via a CD4/ galactosylceramide-independent mechanism. Proc Natl Acad Sci 90: 10474-10478.

Nathanson N, Cook DG, Kolson DL, Gonzalez-Scarano F (1994). Pathogenesis of HIV Encephalopathy. Ann NY Acad Scis 724: 87-106.

Nielsen SL, Petito CK, Urmacher CD, Posner JB (1984). Subacute encephalitis in acquired immune deficiency syndrome: a postmortem study. Am J Clin Pathol 82: $678-682$.

Nottet HSLM, Persidsky Y, Sasseville VG, Nakuna AN, Bock P, Zhai Q-H, Sharer LR, McComb RD, Swindells S, Soderland C, Gendelman HE (1996). Mechanisms for the transendothelial migration of HIV-1-infected monocytes into brain. J Immunol 156: 1284-1295.

Oberlin E, Amara A, Bachelerie F, Bessea C, Virelizier JL, Arenzana-Seisdedos F, Schwartz O, Heard J-M, Clark-Lewis I, Legler DF, Loetscher M, Baggiolini M, Moser B (1996). The CXC chemokine SDF-1 is the ligand for LESTR/fusin and prevents infection by Tcell-line-adapted HIV-1. Nature 282: 833-835.

Paxton WA, Martin SR, Tse D, O'Brien TR, Skurnick J, VanDevanter NL, Padian N, Braun JF, Kotler DP, Wolinsky SM, Koup RA (1996). Relative resistance to HIV-1 infection of CD4 lymphocytes from persons who remain uninfected despite multiple high-risk sexual exposures. Nature Med 2: 412-417.

Peluso R, Haase A, Stowring L, Edwards M, Ventura P (1985). A Trojan Horse mechanism for the spread of visna virus in monocytes. Virology 147: 231-236.

Persidsky Y, Limoges J, McComb R, Bock R, Baldwin T, Tyor W, Patil A, Nottet HSLM, Epstein L, Gelbard H, Flanagan E, Reinhard J, Pirrucello SJ, Gendelman HE (1996). Human immunodeficiency virus encephalitis in SCID mice. Am J Pathol 149: 1027-1053.

Persidsky Y, Nottet HSLM, Sasseville VG, Epstein LG Gendelman HE (1995). The development of animal model systems for HIV-1 encephalitis and associated dementia. J Neurovirology 1: 229-243.

Power C, McArthur RT, Johnson RT, Griffin DE, Glass JD, Perryman S, Chesebro B (1994). Demented and nondemented patients with AIDS differ in brainderived human immunodeficiency virus type 1 envelope sequences. J Virol 68: 4643-.

Price RW, Brew B, Sidtis J, Rosenblum M, Scheck AC, Cleary $P$ (1987). The brain in AIDS: central nervous system HIV-1 infection AIDS dementia complex. $N$ Engl J Med 317: 278-286.
Price RW, Sidtis J, Rosenblum M (1988). The AIDS dementia complex: some current questions. Ann Neurol 23: S27-S33.

Pulliam L, Herndier BG, Tang NM, McGrath MS (1991). Human immunodeficiency virus-infected macrophages produce factors that cause histological and neurochemical alterations in cultured human brains. $J$ Clin Invest 87: 503-512.

Reimann KA, Tenner-Raca K, Racz P, Montefiori DC, Yatsutomi Y, Lin W, Ransil BJ, Letvin NL (1994). Immunopathogenic events in acute infection of rhesus monkeys with simian immunodeficiency virus of macaques. J Virol 68: 2362-2370.

Rhodes RH (1993). Histopathologic features in the central nervous system of 400 acquired immunodeficiency syndrome cases: implications of rates of occurrence. Hum Pathol 24: 1189-1198.

Ringler DJ, Wyand MS, Walsh DG, MacKey JJ, Sehgal PK, Daniel MD, Desrosiers RC, King NW (1989). The productive infection of alveolar macrophages by simian immunodeficiency virus. I Med Primatol 18: $217-226$.

Rot A, Krieger M, Brunner T, Bischoff SC, Schall TJ, Dahinden CA (1992). RANTES and macrophage inflammatory protein $1 \alpha$ induce the migration and activation of normal human eosinophil granulocytes. $J$ Exp Med 176: 1489-1495.

Saito Y, Sharer LR, Epstein LG, Michaels J, Mintz M, Louder M, Golding K, Cvetkovich TA, Blumberg M (1994). Overexpression of nef as a marker for restricted HIV-1 infection of astrocytes in postmortem pediatric nervous tissues. Neurology 44: $478-481$.

Sasseville VG, Lane JH, Walsh D, Ringler DJ, Lackner AA. (1995). VCAM-1 expression and leukocyte trafficking to the CNS occur early in infection with pathogenic isolates of SIV. J Med Primatol 24: 123131.

Sasseville VG, Newman W, Brodie SJ, Hesterberg P, Pauley DR, Ringler DJ (1994). Monocyte adhesion to endothelium in simian immunodeficiency virusinduced AIDS encephalitis is mediated by vascular cell adhesion molecule-1/ $\alpha 4 \beta 1$ integrin interactions. Am I Pathol 144: 27-40.

Sasseville VG, Newman WA, Lackner AA, Smith MO, Lausen N, Beall D, Ringler DJ (1992). Elevated vascular cell adhesion molecule-1 in AIDS encephalitis induced by simian immunodeficiency virus. Am J Pathol 141: 1021-1030.

Sasseville VG, Smith MM, Mackay CR, Pauley DR, Mansfield KG, Ringler DJ, Lackner AA (1996). Chemokine expression in simian immunodeficiencyinduced AIDS encephalitis. Am J Pathol (in press).

Schall TJ, Bacon K, Camp RDR, Kaspari JW, Goeddel DV (1993). Human macrophage inflammatory protein $\alpha$ $(\mathrm{MIP}-1 \alpha)$ and MIP-1 $\beta$ chemokines attract distinct populations of lymphocytes. J Exp Med 177: 18211825.

Schall TJ, Bacon K, Toy KJ, Goeddel DV (1990). Selective attraction of monocytes and $\mathrm{T}$ lymphocytes of the memory phenotype by cytokine RANTES. Nature 347, $669-671$. 
Schmidtmayerova H, Nottet HSLM, Nuovo G, Raabe T, Flanagan CR, Dubrovsky L, Gendelman HE, Cerami A, Bukrinsky M, Sherry B (1996). Human immunodeficiency virus type 1 infection alters chemokine $\beta$ peptide expression in human monocytes: Implications for recruitment of leukocytes into brain and lymph nodes. PNAS 93: $700-704$.

Selmaj KW, Farooq M, Norton WT, Raine CS, Brosnan CF (1990). Proliferation of astrocytes in vitro in response to cytokines, a primary role for tumor necrosis factor. J Immunol 144: 129-135.

Sharer LR, Michaels J, Murphey-Corb M, Hu FS, Kuebler DJ, Martin LN, Baskin GB (1991). Serial pathogenesis study of SIV brain infection. I Med Primatol 20: $211-$ 217.

Simon M, Brodie S, Sasseville V, Chalifoux L, Desrosiers R, Ringler D (1994). Immunopathogenesis of SIVmac. Virus Research 32: 227-251.

Simon MA, Chalifoux LV, Ringler DJ (1992). Pathologic features of SIV-induced disease and the association of macrophage infection with disease evolution. AIDS Res Hum Retroviruses 8: 327-337.

Sinclair E, Gray F, Scaravilli F (1992). PCR detection of HIV proviral DNA in the brain of an asymptomatic HIV-positive patient. J Neuro 239: 469-471.

Smith MO, Heyes MP, Lackner AA (1995). Early intrathecal events in rhesus macaques (Macaca mulatta) infected with pathogenic or nonpathogenic molecular clones of simian immunodeficiency virus. Lab Invest 72: $547-558$.

Springer TA (1994). Traffic signals for lymphocyte recirculation and leukocyte emigration: the multistep paradigm. Cell 76: $301-314$.

Taub DD, Conlon K, Lloyd AR, Oppenheim JJ, Kelvin DJ (1993). Preferential migration of activation CD4+ and CD8+ $\mathrm{T}$ cells in response to MIP-1 $\alpha$ and MIP-1 $\beta$. Science 260: $355-358$.

Tornatore C, Chandra R, Berger JR, Major EO (1994). HIV-1 infection of subcortical astrocytes in the pediatric central nervous system. Neurology 44: $481-487$.
Unger ER, Sung JH, Manivel JC, Chenggis ML, Blazar BR, Krivit W (1993). Male donor-derived cells in the brains of female sex-mismatched bone marrow transplant recipients: a Y-chromosome specific in situ hybridization study. J Neuropathol Exp Neurol 52: $460-469$.

Von Herrath M, Oldstone MBA, Fox HS (1995). Simian immunodeficiency virus (SIV)-specific CTL in cerebrospinal fluid and brains of SIV-infected rhesus macaques. J Immunol 154: 5582-5589.

Watkins BA, Dorn HH, Kelly WB, Armstrong RC, Potts BJ, Michaels F, Kufta CF, Dubois-Dalcq M (1990). Specific tropism of HIV-1 for microglial cells in primary human brain cultures. Science 249: 549-553.

Wiley CA, Achim C (1994). Human immunodeficiency Virus encephalitis is the pathological correlate of dementia in Acquired Immunodeficiency Syndrome. Ann Neurol 36: 673-676.

Wiley CA, Achim CL (1995). Human immunodeficiency virus encephalitis and dementia. Ann Neurol 38: $559-560$.

Wiley CA, Budka H (1991). HIV-induced CNS lesions. Brain Pathol 1: 153-154.

Wiley CA, Schrier RD, Nelson JA, Lampert PW, Oldstone MBA (1986). Cellular localization of human immunodeficiency virus infection within the brains of acquired immunodeficiency syndrome patients. Proc Natl Acad Sci USA 83: 7089-7093.

Wyand MS, Ringler DJ, Naidu YM, Mattmuller M, Chalifoux LV, Sehgal PK, Daniel MD, Desrosiers RC, King NW (1988). Cellular localization of simian immunodeficiency virus in lymphoid tissues: II. In situ hybridization. Am J Pathol 134: 385-393.

Yednock TA, Cannon C, Fritz LC, Sanchez-Madrid F, Steinman L, Karin N (1992). Prevention of experimental autoimmune encephalomyelitis by antibodies against $\alpha 4 \beta 1$ integrin. Nature 356: $63-66$. 